\title{
NEAR NERVE POTENTIAL OF SURAL NERVE IN LEPROSY
}

\author{
Ana Paula M. Arruda', Wilson Marques Jr'2, Norma T. Foss ${ }^{3}$, \\ José A. Garbino ${ }^{4}$, Marcos Virmond ${ }^{5}$, Amilton A. Barreira ${ }^{6}$
}

\begin{abstract}
Leprosy neuropathy is characterized by initial involvement of the small nerve fibers, later followed by involvement of the large fibers, when routine nerve conduction studies become abnormal. To increase the diagnostic yield and precocity of these studies, we applied the near nerve technique to the sural nerve of 8 leprosy patients. Contrary to our expectations, the main component of the sural nerve sensory action potential was abnormal in all patients, but the minimum conduction velocity originating from small 3-6 $\mu \mathrm{m}$ fibers was normal or only mildly involved in three patients. Also, although Schwann cells are the first to be involved in leprosy, the results are suggestive of axonal degeneration instead of demyelination. To better understand the neurophysiology and physiology of leprosy and to increase the accuracy and precocity of the diagnosis, it will be necessary to investigate patients in the very early stages of the disease and to correlate these findings with the corresponding nerve pathology.
\end{abstract}

KEY WORDS: leprosy neuropathy, minimum conduction velocity, near nerve technique, sensory nerve action potential.

\section{Estudo da condução do nervo sural com a técnica de eletrodos justa-nervo em pacientes com moléstia de Hansen}

RESUMO - Na hanseníase, as fibras de pequeno calibre são acometidas antes que as fibras mais grossas, ocasião em que o estudo da condução torna-se anormal. Neste estudo, utilizou-se a técnica de registro com eletrodos justa-nervo com a finalidade de aumentar a precocidade e a acurácia diagnóstica, devido à sua capacidade de detectar potenciais oriundos de fibras com cerca de 3-6 $\mu \mathrm{m}$. Contrário às nossas expectativas, o componente principal do potencial sensitivo do nervo sural foi anormal em todos os pacientes, enquanto a velocidade de condução mínima foi normal ou discretamente alterada em 3 pacientes. Além disso, os resultados são sugestivos de degeneração axonal e não mielinopatia, como seria esperado em uma doença que compromete inicialmente a bainha de mielina. Para um melhor entendimento da fisiologia e fisiopatologia, e para aumentar a precocidade diagnóstica, é fundamental estudar casos bem precoces e correlacionar os dados neurofisiológicos com a respectiva anatomia patológica.

PALAVRAS-CHAVE: estudo da condução sensitiva, moléstia de Hansen, potencial de ação sensitivo, técnica de registro com eletrodos justa-nervo.

The main target of Mycobacterium leprae is the peripheral nerve ${ }^{1}$. In this neuropathy, the small nerve fibers conducting pain and temperature sensations are affected significantly before the large myelinated fibers that conduct vibration sense, position sense, and motor impulses ${ }^{2,3}$. This selective sequential involvement of the nerve fibers impairs the detection of leprosy neuropathy at the initial stages of the disease by neurophysiological evaluation since routine nerve conduction studies only record potentials originating from fibers wider than $7 \mu \mathrm{m}$ in diameter ${ }^{4}$.

We have recently applied the near nerve technique to lepromatous patients to study the sensory nerve action potential (SNAP) of the median nerve at the wrist ${ }^{5}$ in order to assess the contribution of the late components originating from small nerve fibers ranging in diameters from 3 to $6 \mu \mathrm{m}$ and to

\footnotetext{
${ }^{1} \mathrm{MD}$, Master in Neurology, Department of Neurology, School of Medicine of Ribeirão Preto, University of São Paulo, Ribeirão Preto SP, Brazil (SMRP, USP) Supported by CAPES; ${ }^{2} \mathrm{MD}, \mathrm{PhD}$, Associate Professor of Neurology, Department of Neurology, SMPR/USP; ${ }^{3} \mathrm{M} . \mathrm{D}$, $\mathrm{PhD}$, Associate Professor of Dermatology, Department of Internal Medicine, SMRP/USP; ${ }^{4} \mathrm{MD}$, Department of Rehabilitation Medicine and Laboratory of Clinical Neurophysiology, Instituto Lauro de Souza Lima, Bauru SP, Brazil; ${ }^{5} \mathrm{MD}$, PhD, Plastic Surgeon, PqC-6, Instituto Lauro de Souza Lima, Bauru SP, Brazil; ${ }^{6} \mathrm{MD}$, PhD, Professor of Neurology, Department of Neurology, SMRP/USP.
}

Received 19 January 2004. Accepted 12 April 2004.

Dr. Wilson Marques Jr. - Departamento de Neurologia / Faculdade de Medicina de Ribeirão Preto - Av. Bandeirantes 3900 - $14049-900$ Ribeirão Preto SP - Brasil. E-mail: wmjunior@fmrp.usp.br 
improve the earlier detection of nerve injury in leprosy. As the median nerve is not suitable for biopsy, after the previous study we decided to apply the same technique to investigate the late components of the SNAP of the sural nerve, where nerve biopsies are usually carried out, allowing correlative studies between morphology and physiology. We believe these studies will not only improve our knowledge about neurophysiological findings in leprosy and its clinical applications, but will also improve our understanding of the physiology of this neuropathy.

\section{METHOD}

We studied the sural SNAP from 8 patients with leprosy and 10 normal controls. The disease was classified as multibacillary in 5 patients and paucibacillary in the remaining 3. Both patients and controls denied alcohol or drug abuse, diabetes mellitus and hereditary conditions. A metabolic screening for the most common causes of neuropathies was also peformed.

The near nerve technique was performed as described by Shefner et al. ${ }^{6}$, with the modifications introduced by Marques and Barreira ${ }^{7}$. Briefly, the patient was comfortably positioned in lateral or ventral decubitus, with the leg in complete relaxation. The area to be examined was carefully cleaned with water, soap and ether. The stimulating electrodes were positioned at the ankle, with the cathode being proximal to the anode. The needle recording electrodes were positioned $14 \mathrm{~cm}$ proximally in a unipolar recording arrangement. The position of the active recording electrode was carefully adjusted near the nerve, so that when the electrode was used to stimulate, an intensity as low as 0.5 to $1 \mathrm{~mA}$ was able to evoke a response at the ankle, implying that the distance between the needle and the nerve is 0.5 to $1 \mathrm{~mm}$, considered to be the ideal position for the method. Filter settings were 200 and $3000 \mathrm{~Hz}$, analysis time was $40 \mathrm{~ms}$, the number of averaging ranged from 500-2000 sweeps per trial, and at least 2 trials were executed. A sensitivity of $5-20 \mu \mathrm{V}$ was used to measure the amplitude and latency of the main component, while the late component was recorded with a sensitivity of $5 \mu \mathrm{V}$ and a gain of 0.1 to $1 \mu \mathrm{V} /$ division was used to measure its latency and amplitude. Temperature was kept above $33^{\circ} \mathrm{C}$.

Thie study was approved by the Ethics Committee of our University Hospital and of the Institute Lauro de Souza Lima. All patients and controls gave informed consent.

\section{RESULTS}

Mean age was 35.8 years (range: $19-58$ years) for the controls and 48.5 (range: $28-72$ years\} for the patients. SNAP data for the sural nerves of controls and patients are presented in Tables 1 and 2, respectively. The main component and the late compo-
Table 1. Electyrophysiological evaluation of the sural nerve using the near nerve technique in normal controls.

\begin{tabular}{lccccc}
\hline \multirow{2}{*}{ Controls } & \multicolumn{2}{c}{ Main component } & & \multicolumn{2}{c}{ Late component } \\
\cline { 2 - 3 } \cline { 6 - 6 } & CV & Ampl & & MCV & Ampl \\
\hline 1 & 48.3 & 15.0 & & 14.9 & 0.3 \\
2 & 58.3 & 21.0 & & 11.1 & 0.1 \\
3 & 56.0 & 24.0 & & 17.1 & 0.2 \\
4 & 56.0 & 11.0 & & 16.9 & 0.1 \\
5 & 59.1 & 24.0 & & 15.7 & 0.2 \\
6 & 64.3 & 39.0 & & 17.3 & 0.2 \\
7 & 57.1 & 30.0 & & 17.9 & 0.1 \\
8 & 45.2 & 15.0 & & 18.4 & 1.2 \\
9 & 44.8 & 12.0 & & 18.3 & 0.1 \\
10 & 60.9 & 24.0 & & 14.0 & 0.1 \\
\hline
\end{tabular}

Ampl, amplitude $(\mu \mathrm{V}) ; \mathrm{CV}$, conduction velocity $(\mathrm{m} / \mathrm{s}) ; \mathrm{MCV}$, minimum conduction velocity.

Table 2. Electyrophysiological evaluation of the sural nerve using the near nerve technique in patients with leprosy.

\begin{tabular}{|c|c|c|c|c|}
\hline \multirow[t]{2}{*}{ Patients } & \multicolumn{2}{|c|}{ Main component } & \multicolumn{2}{|c|}{ Late component } \\
\hline & CV & Ampl & MCV & Ampl \\
\hline 1 & $\mathrm{NR}$ & NR & 8.6 & 0.1 \\
\hline 2 & NR & NR & NR & NR \\
\hline 3 & 38.2 & 1.6 & 12.7 & 0.1 \\
\hline 4 & 45.2 & 1.6 & 3.1 & 0.2 \\
\hline 5 & 55.0 & 5.2 & 23.6 & 0.1 \\
\hline 6 & NR & NR & $N R$ & NR \\
\hline 7 & NR & NR & 15.1 & 0.1 \\
\hline 8 & NR & NR & NR & NR \\
\hline
\end{tabular}

nents were recorded in only 3 and 5 patients, respectively. The mean amplitude of the main component was $21.5 \mu \mathrm{V}$ (SD 8.71) for the controls and 2.8 $\mu \mathrm{V}$ (SD 2.07) for the patients, while the values for conduction velocity were $55.0 \mathrm{~m} / \mathrm{s}$ (SD 6.67) and $46.13 \mathrm{~m} / \mathrm{s}$ (SD 8.43). The mean conduction velocity of the late component, minimum conduction velocity (MCV), was $16.16 \mathrm{~m} / \mathrm{s}$ (SD 2.30) for the controls and $12.25 \mathrm{~m} / \mathrm{s}$ (SD 8.55) for the patients; the limits, however, ranged from 11.1 to 18.4 in the first group and from 3.1 to 23.6 in the second group, considering only the recorded potentials. Amplitudes were similar. 
No response was recorded in the sural nerves of patients 2, 6 and 8; in patients 1 and 7 the main component was not recorded, but the late component was normal; the main component of patients 3,4 and 5 had normal or mildly decreased conduction velocities and severely decreased amplitudes, while the behavior of the MCV was extremely variable, being normal in patient 3 , extremely reduced in patient 4 and too high in patient 5 .

\section{DISCUSSION}

Shefner et al. ${ }^{6}$ applied the near nerve technique to patients with peripheral neuropathy and found that in $31 \%$ of them the only electrophysiological abnormality present was an abnormal late component of the SNAP, demonstrating the efficacy of this technique in the study of potentials arising from nerve fibers ranging from 3 to $6 \mu \mathrm{m}$ in diameter, that are not recorded in routine nerve conduction studies ${ }^{4}$. Considering that in the initial phases of leprosy there is a predominant involvement of unmyelinated fibers, following impairment of small myelinated nerve fibers ${ }^{2,8}$, we decided to investigate the contribution of the near nerve technique to increase the diagnostic yield of nerve conduction studies in leprosy, since an early diagnosis results in early treatment, the best measure to avoid the feared consequences of leprosy neuropathy, including painless ulcerations, and muscle atrophy and weakness ${ }^{3}$.

Recently, Marques et al. ${ }^{5}$ applied the near nerve technique to study the sensory fibers of the median nerve is newly diagnosed leprosy patients. Unfortunately, the median nerve is not accessible to biopsy, preventing morphological analysis in those cases with detected neurophysiological abnormalities. This is not the case for the sural nerve, an exclusively sensory nerve whose morphology has been extensively studied in peripheral neuropathies, including leprosy.

All nerves analyzed in this series were abnormal, but the findings were not homogeneous. In patients 2, 6 and 8 no SNAP was recorded, suggesting complete axonal degeneration of all nerve fibers. Patients 1 (Fig 1) and 7 did not have the main component, but the late component was present, with mildly decreased and normal conduction velocities, respectively, suggesting degeneration of the large fibers but preservation of those fibers that give origin to the observed late components. Patients 3, 4 and 5 had a low amplitude main component with preserved or only mildly decreased conduction ve-

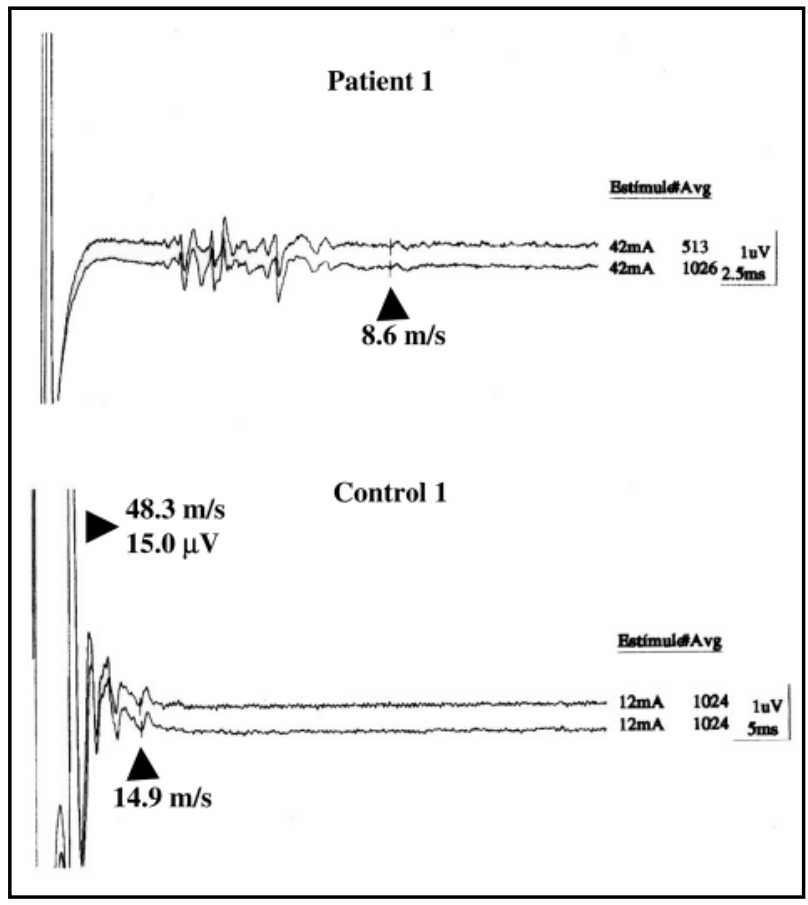

Fig 1. Near nerve recordings from the sural nerve. The upper trace shows patient 1 recording, showing absence of the main component and several abnormal intermediate components. The latest component is identified by a vertical arrow. The lower trace shows control 1 examination, with normal main (horizontal arrow) and latest components (vertical arrow).

locities, suggesting loss of the large fibers that give origin to these components. The MCV of these nerves were highly different, being normal, extremely reduced or moderately increased, respectively suggesting preservation of the fibers that give origin to the late component, regeneration or demyelination, and loss of the small fibers.

The abnormalities found in the main component were relatively homogeneous, always suggesting axonal loss, a finding already reported by many authors ${ }^{5,8-13}$, but is not in perfect agreement with the proposed physiology of this neuropathy since Schwann cells are the first to be involved by the bacilli $^{14,15}$. This theoretically implyies that demyelination should be the first abnormality detected, as was reported by Tzourio et al. ${ }^{16}$ for the superficial radial nerve from recently diagnosed patients.

Confirming our previous study 5 , the analysis of the late component, paradoxically, did not add too much to the neurophysiological evaluation of these patients since the main component was always abnormal, even in the two patients ( 3 and 6 ) with preserved MCV. As discussed in that paper, the origin of these normal late components must be investigated. We suppose that they may be produced by ab- 
normal fibers whose electrophysiological behavior is similar to that of normal 4-6 $\mu \mathrm{m}$ fibers. We also hypothesize that the findings observed in patients 3 , 4 and 5 may represent the sequence of events involving the small fibers in this neuropathy. Initially, there is loss of the these fibers, and the last recorded components have an MCV proportional to the diameter of the remaining fibers, higher than the normal values for a late component, as observed in patient 5. Regeneration may then occur, giving origin to late components with extremely reduced conduction velocities (patient 4). Eventually, these regenerating components may show a behavior electrophysiologically similar to that of normal 3-6 $\mu \mathrm{m}$ fibers, with the occurrence of an electrophysiological "normal" late component originating from abnormal nerve fibers.

As an affected nerve may function normally in leprosy ${ }^{17}$, it is possible that all patients studied in this series had advanced disease, even those with mild manifestations. If this assumption is true, we may be studying nerves that show a significant degree of axonal degeneration, regeneration and even remyelination. The definitive understanding of all these findings and assumptions will probably be reached with the evaluation of patients in the very early stages of the disease, studied not only distally but also at the topography were the initial attack occurs, and with studies analyzing both morphology and electrophysiology.

\section{REFERENCES}

1. Minauchi $Y$, Igata A. Leprous neuritis. In Matheus WB. Handbook of clinical neurology: neuropathies. Amsterdam Elsevier 1987;215-238.

2. Gibbels E, Henke-Lübke U, Klingmüller G. Unmyelinated nerve fibers in leprosy: a quantitative and qualitative study of sural nerve biopsies in two cases of lepromatous leprosy. Lepr Rev 1988;59:153-162.

3. Sabin TD, Swift TR, Jacobson RR. Leprosy. In Dyck PJ, Thomas PK, Griffin JW, Low PA, Poduslo JF, (EDS). Peripheral neuropathy, 3rd ed. Philadelphia: Saunders, 1993;1354-1379.

4. Buchthal R, Rosenfalck A, Behse F. Sensory potentials of normal and diseased nerves. In Dyck PJ, Thomas PK, Lambert EH, Bunge R, (EDS). Peripheral neuropathy, 2nd ed. Philadelphia: Saunders, 1984;981-1015.

5. Marques W Jr, Foss NT, Arruda AP, Barreira AA. Near-nerve in lepromatous leprosy. Muscle Nerve 2003;28:460-463.

6. Shefner JM, Buchthal F, Krarup C. Slowly conducting myelinated fibers in peripheral neuropathy. Muscle Nerve 1991;14:534-542.

7. Marques W Jr, Barreira AA. Normal median near nerve potential. Braz J Med Biol Res 1997;30:1431-1435.

8. Anthia NH, Mehta LN, Shetty VP, Irai PF. Clinical, electrophysiological, quantitative, histological and ultrastructural studies of the index branch of the radial cutaneous nerve in leprosy: 1. Preliminary report. Int J Lepr 1975;43:106-113.

9. Dastur DK, Ramamohan Y, Shah JS. Ultrastructure of lepromatous nerves: neural pathogenesis in leprosy. Int J Lepro 1973;41:77-80.

10. Ramakrishnan AG, Srinivasan TM. Electrophysiological correlates of hanseniasis. Int J Leprosy 1995;63:395-408.

12. Freitas MR, Nascimento OJ, Quaglino EA, Hanh MD. Small-fiber polyneuropathy in leprosy without skin changes: study of 17 cases. Arq Neuropsiquiatr 2003;61:542-546.

13. Jardim MR, Antunes SL, Santos AR, et al. Criteria for diagnosis of pure neural leprosy. J Neurol 2003;250:806-809.

14. Rambukana A. How does Mycobacterium leprae target the peripheral nervous system? Trends Mycrobiol 2000;8:156-157.

15. Rambukana A, Zanazzi G, Tapinos M, Salzer JL. Contact-dependent demyelination by Mycobacterium leprae in the absence of immune cells. Science 2002;296:862-863.

16. Tzourio C, Said G, Millan J. Asymptomatic nerve hypertrophy in lepromatous leprosy: a clinical, electrophysiological and morphological study. J Neurol 1992;239:367-342.

17. Mcleod JG, Hargrave JC, Walsh JC, et al. Nerve conduction studies in leprosy. Int J Lepr 1975;43:21-31. 